\title{
Time, Timing, Timetabling: Critical Elements of Successful Graduation of High School ESL Learners
}

\section{Hetty Roessingh and Diane Field}

As we begin the new millennium, it is clear that the classrooms of today are unlike those of the past. The most visible change has been the diversity now present in our high schools, reflected in the large numbers of students who are learning English as a second language. These students are in the process of developing English language proficiency at the same time as they are pursuing high school graduation requirements. School administrators can apply what is known about the process of developing English language proficiency when making decisions about deployment of staff and building their school timetable. When time, timing, and timetabling converge in a school plan that permits the development of English language proficiency while ESL students are in the mainstream, the success of ESL students can be greatly enhanced.

\section{Introduction}

Constructing a high school timetable is a time-consuming, complicated endeavor that requires consideration of myriad factors. Many of these place conflicting pressures on the timetable: building use or occupancy rate, technology, community and business linkages, staffing or staff expertise, learner profiles and needs of the students. As Schroth (1997) observes, it is these latter factors that should drive the timetable. Kentta (1993) notes that instructional goals need to be identified first. Only then can the work of constructing a timetable proceed.

The demographics of Canada and consequently our classrooms across the nation are changing rapidly due to changes in immigration patterns over the past decade. Although diversity remains a key feature of our immigrant population-and hence the programmatic responses required to meet a variety of needs-three distinct new trends of the past decade have a direct impact on our work as educators. These include the increased number of immigrants to Canada (the target for 2000 is 300,000 new arrivals: Duffy, 1999), the federal government's policy of recruiting skilled workers and business-class immigrants (Employment and Immigration Canada, 1985), and the concentration of immigrants from Pacific Rim countries (Citizenship and Immigration Canada, 1997). In addition to the influx of students through normal immigration channels, many school jurisdictions actively recruit visa 
students at the high school level. Large urban school districts such as Vancouver (Rinehart, 1996), Toronto (McInnes, 1993), and Calgary (Dawson, 1998; Dempster \& Alberts, 1998) estimate that $20-50 \%$ of the general school population is of an English-as-a-second language background.

The learner profile that emerges from the demographic data is ESL learners who are academically competent and who in larger numbers than ever before speak Cantonese as their first language (Citizenship \& Immigration Canada, 1997). Many of these learners have goals for university entrance and are under pressure, both self-imposed and parentally imposed, to "fast track" toward their academic goals. Critical to their realization of these goals is the development of English language proficiency to the degree required for successful completion of academic course work at the high school level, in particular, the academic literature course(s) required for university registration.

The idea of timing or readiness for ESL learners to engage in academic content area study is not new. Many school jurisdictions support a philosophy of proportional or staged integration for high school ESL learners. They are integrated into the academic mainstream gradually while they are still receiving direct ESL instructional support. The pattern of integration is typically initiated with mathematics and science where there is more contextual support for deriving meaning and developing English language proficiency, moving on to social studies, and finally English literature. In this article we attempt to refine our understanding of how the practice of proportional integration can work with the critical element of time to enhance the possibility of educational success for ESL learners. Identifying linguistic thresholds for each stage of integration, both through standard measurements and ESL students' reflection on their academic success gives precision to the notion of timing.

The purpose of this article is to examine issues related to time, timing, and timetabling and to discuss how the timetable can be constructed to support the development of English language proficiency in a three-year plan leading to university entrance for academically competent ESL learners, using a semester system. The article will be of interest to school administrators, guidance counselors, mainstream English teachers, and ESL teachers who together can collaborate in (a) making decisions that will have an impact on the timetable, and (b) making timetabling or course selection and course sequencing decisions for ESL learners. This article is written for an audience of ESL teachers because we expect that the ESL teacher will serve as the catalyst for change.

\section{Background}

A recently released study of Canadian immigration highlights three factors critical to Canada's future: a shift to a technology-based economy (the "new 
economy"), the importance of advanced education to develop the skills required to engage in the new economy, and immigration as the primary solution to the aging of the Canadian population (Jedwab, 2000).

The educational success of ESL learners has been the focus of a number of research studies conducted across Canada. Various tracking studies (Radwanski, 1987; Alberta Education, 1992; Watt \& Roessingh, 1994, 2000; Derwing, de Corby, Ichikawa, \& Jamieson, 1999; Eddy, 1999) come to essentially the same conclusion, that is, that successful high school graduation remains an elusive goal for most ESL learners. Even among the most academically competent ESL students, dropout ranges from $50-70 \%$, and the overwhelming majority of ESL learners in Alberta do not meet with success on the provincial departmental examination for English 30, the academic English course required for entrance into university (Alberta Education, 1997; Watt \& Roessingh, 2000).

Like most provinces, Alberta has a dual-track system, or two streams, through high school: an academic track leading to university entrance (university faculties set their own specific requirements) and a general track leading directly to the workplace or to postsecondary school opportunities that do not require a full academic diploma. Most recent newcomers, academically competent ESL learners, have academic aspirations, that is, university entrance. They may be required to present between four and six provincially examinable grade 12 subjects depending on the faculty of registration.

Watt and Roessingh's (2000) 10-year tracking study identifies situational factors in the educational trajectory of ESL learners where they are most at risk for failure and dropout. Premature exit from ESL programs (or, conversely, premature integration in mainstream academic course work) and the lack of ongoing ESL support as students make progress toward graduation appear to account for students' unpreparedness for the gatekeeping function of departmental examinations. A number of innovations in ESL programs and timetabling can enhance the possibility of success for ESL learners by targeting ESL support in the educational trajectory at times when students are most at risk of failure and dropout (Roessingh, 1999).

We begin by providing background information on the needs of academically competent ESL learners. This provides a rationale for a pattern of integration into academic content area courses that recognizes minimum linguistic thresholds necessary for success in mathematics, chemistry, physics, biology, social studies, and English literature. It describes the type of ESL support that is required at critical points of integration into mainstream content area study. It provides a sample template for successful high school completion within three years, which includes summer school attendance after grade 10 and 11 . Following this, we report on the perceptions of high school graduates who have been invited to reflect on and explain their 
success following the three-year plan. We conclude with a call for flexibility and a focus on students' learning needs in the design of the school timetable. Administrators can make better-informed decisions if they understand the critical elements of time and timing and apply these understandings to constructing school timetables that will allow for successful high school graduation.

\section{Learning a Second Language and the Needs of the New Wave of ESL Learners}

Learning a second language is a long and uneven process. Various studies (Cummins, 1982, 1994; Collier, 1987, 1989) suggest that it takes about two years for beginner ESL students to become proficient with basic interpersonal communication skills (BICS) and from five to seven years (and longer) to develop the academic language required for success in all areas of the curriculum. The key realization that emerges from these studies is that BICSlevel English is not sufficient for success in an academic environment.

Most newly arriving high school ESL learners from Pacific Rim countries are academically competent, have already acquired some English-typically to grade equivalent (GE) 4-5 in reading, and expect to complete high school graduation requirements within a two to three-year time frame. In addition, many of these students must sit the TOEFL examination to gain entrance to university. They are "in a hurry" and it is important that their ESL program is perceived to advance their educational mainstream goals (Kanno \& Applebaum, 1997).

The English language proficiency that these learners generally have acquired in their country of origin has been taught in a traditional or conservative framework (i.e., grammar or translation, drills, teacher-fronted rote learning) in large-class settings (i.e., 50-70 students in a class) by a teacher who is not a native speaker of English. Thus although the students have acquired the basic skills, they lack the interpersonal communication skills of the BICS equation (Foscolos, 2000). In addition, they need to acquire cultural information and study skills in order to adjust to and succeed in the educational milieu of high school in Canada.

Students described above and placed in grade 10 can benefit from a year of ESL programming aimed at developing conversational (interpersonal communication) skills and transitional academic skills on topics of interest to teenagers (e.g., fashion, music, advertising, heroes) as well as developing study strategies in topics or theme studies that are loosely aligned with mainstream curriculum (e.g., endangered species). The goal is to develop vocabulary, increase reading abilities to GE 7 , and build academic writing skills relevant to engagement with a literature course and other areas of content study where, increasingly, good writing skills are in demand. 
ESL learners can also attend academic mathematics and certain science courses because the linguistic threshold for success in these environments is lower than in courses such as social studies and English literature. Students from Pacific Rim countries often have studied a more advanced mathematics and science curriculum, and they are already familiar with the concepts that will be presented in mathematics, chemistry, and physics. This content, therefore, acts as an ideal vehicle for the development of English language proficiency-students are translating concepts or content knowledge they already have, a far less onerous task than acquiring these in a mainstream setting for the first time in a language they do not have under control. Kessler (1987) and Roessingh (1996) have recorded gains in English language proficiency in ESL learners integrated into high school science. It is important to note, however, that study materials must be kept at the comprehensible input level and slightly above (i+1) ranging in GE of 5-7. Further, teachers need to make a variety of modifications in their "teacher talk" in order for this speech to be useful as raw data in developing English language proficiency among their ESL learners (Chiang \& Dunkel, 1992), and learning tasks need to promote communicative competence for the students (rather than be primarily paper-and-pencil driven).

ESL learners are safely able to accelerate their mathematics and science study (chemistry and physics, not biology), enrolling in grade 11 course work in the second semester of grade 10 . This is often seen by them as an acceptable trade-off for the delay in registering in a literature course. It is also a timetabling strategy that will allow these students to complete their high school requirements within a three-year time frame.

ESL learners may register for a social studies course next in the sequence of academic courses (second semester, grade 10). Some schools offer sheltered social studies (open only to ESL students at the grade 10 level), or transitional social studies (offered by the ESL department). A key feature of transitional programming is the language learning focus placed on academic content area instruction. The ability to offer sheltered and transitional classes will depend on numbers of students and staff expertise.

Sometimes it makes sense to place academically competent ESL learners in the nonacademic track. A case in point would be social studies, a core subject required in Alberta for high school graduation, but not for university entrance. Another example is to use nonacademic settings as transitional courses to the academic mainstream. Generally, however, having acquired the minimum linguistic threshold thought necessary for success in an ESL setting, academically competent ESL learners need to be placed directly into academic track courses, and their teachers need to be able to make appropriate modifications for them at the classroom level. This will need to become a focus of professional development in the future. 
ESL learners can register in their first mainstream literature course when reading scores reach GE 7 , typically in the first semester of their grade 11 year. If possible this course should be sheltered, meaning that it includes only ESL students, but is taught by an English literature teacher, possibly with the benefit of adjunct support provided by an ESL teacher (Roessingh, 1999). Adjunct programming for ESL learners emphasizes the acquisition of the linguistic skills, direct instruction of underlying concepts, and learning strategies relevant for success in the content area with which it is linked (i.e., academic English literature study). The sheltered English and adjunct ESL courses need to be offered together on the timetable for equal contact hours and credit and carefully linked by the two instructors, who may plan collaboratively for the content and language goals. ESL students remain linguistically disadvantaged compared with their academically competent native English-speaking peers throughout high school, and it is important that they continue to develop their English language proficiency while they are integrated, particularly in linguistically demanding courses such as English literature.

The linguistic proficiencies pertinent to academic success are summarized in Table 1. This information can help both mainstream and ESL teachers in planning for language learning goals.

Tracking of quantitative results of sheltered English 10/adjunct ESL support (Roessingh, 1999) suggests that ESL students are capable of becoming academically competitive and holding their own (with tutorial support) in the next level of literature study, English 20. Reading scores for ESL learners continued to reflect gains while they were registered in sheltered English 10. However, with the move to grade 11 English students' needs begin to shift, and they require ongoing support.

ESL learners can be fully integrated in grade 11 literature (English 20) in the second semester of grade 11 with tutorial ESL support. The focus of the tutorial sessions is instructional conversations and frontloading to clarify and offer background knowledge or cultural specific references, to edit the students' work, and simply to provide processing time for the reading burden imposed by an academic literature course. The same support is provided in the grade 12 literature course (English 30), which students can attempt in the first semester of grade 12.

It becomes clear from the above discussion that ESL learners remain linguistically disadvantaged throughout their high school studies. They are forever chasing a moving target as they attempt to close the gap between themselves and their native English-speaking classmates sufficiently to compete academically. The challenge, therefore, is to structure a high school plan that will address the evolving and changing needs of the new wave of ESL learners as they make their way through high school and attempt to fulfill university entrance requirements-including the English literature course, 
Table 1

Linguistic Proficiencies

ESL learners

5,000-7,000-word vocabulary ${ }^{1}$

reading speed approx. $100 \mathrm{wpm}$ (narrative

materials)

reading grade equivalent at least GE 7

difficulty with writing in expository mode

familiar with standard English only

lacking experience with puns, double meanings,

idioms

read for literal meaning level

the language of imagery, symbolism, metaphor is a challenge
Native English Speaking Learners

40,000-word vocabulary ${ }^{2}$

approx. 300 wpm

reading at grade level (10) or higher

writing skills assumed

familiar with a variety of dialects (e.g., Ebonics, the

language of children)

enjoy humor based on language

read at the interpretive level

able to use language to access abstract thought

'Grabe (1987). ${ }^{2}$ Miller and Gildea (1991).

the single course that too often acts as the solitary gatekeeper between high school and university entrance for these students.

In the following section, a sample template is provided for a three-year timetable that will permit high school graduation with the entrance requirements of Alberta universities. The salient features of the three-year plan are explained.

\section{A Three-Year Plan}

Table 2 illustrates a three-year high school plan for ESL learners that will permit successful graduation with academic requirements for entrance into most faculties at university, keeping in mind that electrical engineering, computers, business or commerce, and hard sciences tend to be the programs of choice at university for ESL learners (personal communication, ESL Department, University of Calgary).

Time, timing, sequencing, and careful distribution of the academic work load make this plan work for many ESL learners. The following features of the plan should be noted:

- A structured ESL program that extends support as the students' needs change and evolve. It includes adjunct support and tutorials for English 10, 20,30 - the academic sequence of English literature courses in grades 10,11 , and 12 respectively.

- Direct placement in academic English literature courses on reaching the linguistic threshold recognized for success in an ESL context. Academically competent ESL learners should not have to traverse through nonacademic course work to reach their mainstream goals. 
This places these students at academic risk of early and low plateau, fossilization, failure, and dropout (Roessingh, 1996).

- Sheltered English 10.

- Acceleration of mathematics, physics, and chemistry study beginning in the second semester of grade 10.

- Enrollment in summer school to unload some of the academic burden. Courses for summer school are limited to mathematics, chemistry, physics, or social studies (required for high school graduation, but not university entrance).

- Delay enrollment in English 10 until grade 11, GE 7 in reading scores.

- Delay enrollment in biology courses until the student has developed sufficient English language proficiency (GE 8).

- Completion of one or two grade 12 courses requiring a departmental examination in grade 11 to lessen the burden in grade 12. Five or six departmental examinations in grade 12 would be overwhelming.

- Provision made to challenge a Chinese (or other) language exam in order to obtain credits required for graduation. Students focus on core academics and have very little time for complementary courses.

- Possibility in grade 12 to repeat English 30 (academic grade 12 English) if necessary in the second semester.

- Flexibility in the course sequencing to permit an additional English literature course after English 10 as a kind of "booster" before advancing to English 20. This is English 23, a nonacademic English literature course that offers the opportunity to develop English language proficiency if necessary (students have scored less than $65 \%$ in English 10).

Note that after grade 10 the workload is significant, even for students who are used to long hours of work and who have good study habits. Care needs to be taken to monitor and coach students in pacing themselves to complete the work. Overwork and the consequent fatigue from sleep deprivation can lead to burnout, another reason to plan the students' timetables carefully. There is little flexibility in the timetable to repeat failed courses.

Not all of the ESL students will require as much direct ESL support as has been permitted in grade 10 . There is always a range of proficiency levels in any intake cohort. If students reach the linguistic threshold for English 10 (GE 7) by the end of the first semester, they may take a course from the complementary offerings (e.g., word-processing, food preparation) or accelerate their mathematics program. The template illustrated in Table 2 is only a sample, and individual schools will need to experiment to find what will work for them.

Adopting this approach to timetable planning will have implications for staff deployment and development. The English teacher who works with the 
Table 2

Sample Template for a Three-Year High School Program, Based on a Semester System

Semester 1

\begin{tabular}{lll}
\hline Grade $10^{1}$ & Grade 11 & Grade 12 \\
ESL & English 10: sheltered & English 20 or English 30 \\
ESL or CTS & ESL Adjunct & ESL tutorial \\
PE 10 & Social Studies 23 & Math 30 \\
Math 10 & Physics, Math, or Chemistry 20 & Physics 30 or Chemistry 30 \\
& & or Biology 20
\end{tabular}

Semester 2

\begin{tabular}{lll}
\hline ESL & English 20 or 23 & English 30 \\
$\begin{array}{l}\text { Science } 10 \\
\text { Social Studies } 10\end{array}$ & ESL tutorial & ESL tutorial \\
CALM/CTS, or Math 20 & Social Studies 33 & Chemistry 30 or Physics 30 \\
& Physics, Math or Chemistry 30 & Math 31 or Biology 30 \\
\hline $\begin{array}{l}\text { Summer school: } \\
\text { Math 20 or }\end{array}$ & Summer school: & Summer school: \\
Physics 20 or & Math 20 or & Biology 30? \\
Chemistry 20 & Physics 20 or & \\
\hline
\end{tabular}

'Courses beginning with a 1 are grade 10 level, 2: grade 11, 3 grade 12. Courses ending in " 0 " are academic track courses, those ending in 3 are nonacademic track. Math 31 is an advanced calculus course required by the Faculty of Engineering.

${ }^{2}$ Career and Technology Studies: note that students must present 10 credits (the equivalent of two full courses) in CTS for graduation requirements. Many students can do this by presenting Chinese credits earned at Saturday school or by challenging the Chinese exam set by the local school board. Some students decide to focus on university faculty entrance requirements and forfeit a high school diploma. No faculty requires $C T S$ credits.

Note: Alberta Learning, the Ministry for education in Alberta, allocates only 15 credits (the equivalent of 3 full courses of 125 instructional hours each) for ESL programming at the high schoof level. Other credits, such as Reading 10 , Communications $21 A / B$, may be assigned to students' instructional programs. ESL students, however, often spend hundreds of hours in ESL class settings for no credit. ESL students capture the full funding for credit equivalent units (CEUs) whether or not their ESL time is assigned credit. Supplementary funding for ESL as well as the three year cap is in flux in Alberta at the present time.

For more information on credit equivalents and course requirements for graduation, consult the Alberta Learning Web sites: www.alis.gov.ab.ca or http://ednet.edc.gov.ab.ca.

ESL students in sheltered English 10 will need to become sensitive to the language learning needs of ESL learners and to work closely with the ESL teacher (Roessingh, 1999). Because of how the English courses are sequenced, there may be pressure on the English department in the grade 11 year of the three-year plan. On the other hand, because so many ESL students choose to attend summer school, there will be less demand for science course offer- 
ings-but more time required for ongoing ESL support. It is suggested that one guidance counselor develop understanding of the needs of ESL learners and be assigned the task of planning and monitoring their high school programs, including their summer school and university registration. Summer school courses need to be chosen with care. After ESL learners have left the sheltered English 10, they need to be clustered together for English 20 and 30 in order to make the best use of their tutorial time (which also needs to be timetabled carefully). These are just a few examples of how administrators, guidance personnel, ESL teachers, and mainstream English teachers are affected by the presence of significant numbers of ESL learners in the school.

\section{Students' Perceptions of Their Educational Experiences}

It should be possible for many high school ESL learners from Pacific Rim countries who arrive with upper intermediate or advanced-level English language proficiency to complete high school graduation requirements and make their way to university.

Quantitative data collected by way of tracking studies or pass-fail rates on departmental examinations, however, do not offer insights into the quality of educational experiences of Pacific Rim ESL learners and their perceptions of their high school careers. In order to gain these insights, we invited 12 ESL learners to share their perceptions of their successes following a semistructured interview protocol. This was followed with a questionnaire (Appendix) that asked the students to reflect on their success, to construct a three-year plan that would allow for university entrance, and to think back to that first day in high school: "What advice would you give to such a student now that you know what it takes to succeed?" These data were analyzed to identify emergent and recurring themes within and across the data, consistent with the methodology of grounded theory (Strauss, 1987; Bogdan \& Biklen, 1992).

Both within and across the student narratives and questionnaires, the theme of time emerged as a salient feature of academic success. Timing (readiness), sequencing, distribution of workload, and just time (time to read, time to do homework, time to write or rewrite papers) are clear concerns of academically competent students who do not perceive that they have the time. These ideas are expressed in the following ways:

S: Go for the easy courses when you are ready, like Math 20. Delay English and social studies for later. Leave a block for ESL help when you take an English course.

$R$ : I think it's better to put English 10 aside in grade 10 and take Math 20 and Chem 20 first since they are not very hard and the student can have more time to develop their English before going into English 10 in grade 11. 
These concerns have emerged from other qualitative studies of immigrant students' success (Watt, Roessingh, \& Bosetti, 1996; Foscolos, 2000).

Without exception the students identified summer school attendance as a strategy for "buying time" from September to June to plan a reasonable workload. It is explained this way by the students:

$R$ : You need to unload something from grade 11 at summer school (after grade 10).

C: In summer school, you should take some easy course. Math 20 should be the suitable one. By the way, you should take Math 20 before taking any grade 11 science courses because science subjects like physics, chemistry, biology still need some math skills and students will find the courses easier after they have got the math skills.

Summer school was also seen as a good opportunity to fulfill the social studies requirement for high school graduation. Because this course is almost never a requirement for university entrance into the faculties of choice for these students, they do not perceive this course as significant in their educational plans. The students often perceived themselves as busy peoplesometimes too busy. Some of the students would have enjoyed more time for option or complementary courses, and they voiced regret at not having had the time for this. Some would also have enjoyed a more active student life in sports, student council work, and social events.

R: I wish I could take an option in grade 10.

A: There wasn't enough time to do option courses. I didn't have enough fun. It's too intense to go through high school like this. I wanted a gym class.

S: I am sorry I didn't get involved much in school activities or clubs.

On the other hand, some students thrive on the busyness of their lives and enjoy the challenge of hard work. They look forward to summer school both to advance their coursework, and to meet other ESL learners from other high schools who are using the summer for study purposes. They do not mind sacrificing their option program in order to focus only on academic work, and graduate successfully within three years. Part-time work, volunteer work, or just having a summer off ("just get lazy") are not generally valued by the students or their parents, although many students do plan to return to Hong Kong or Taiwan to visit friends and family and go shopping after completing summer school.

T: For me, it was a wrong choice of taking Band in grade $10 \ldots$. this wasted time.

The students clearly value their ESL support at every stage of their educational progress and integration into mainstream course work, especially when they are timetabled for a literature course. They recommend an ESL 
block of time to support the literature course, and they would choose the other two academic courses (in addition to literature) with care.

R: Take an easy course like Chem 30 or Math 31 with English 30, so there will be more time. English has to have an ESL block, so there will be time to work.

A: Try to put ESL in every semester. The work is very heavy, especially in grade 12.

S: Leave a block for ESL help when you take an English course.

Their final words of advice to younger incoming students include the following comments:

A: Study when you can or you will regret.

S: No pain, no gain!

C: Come to Canada one year earlier! (this student came at age 16)

$R$ : Don't give up! It will pay off at the end.

$\mathrm{R}$ : Get a conversation partner in grade 10 like I did with lovely Katie!

\section{Conclusion}

The demographics of our high school population are changing quickly and noticeably in major urban settings. The rising numbers and concentration of students from Pacific Rim countries with high educational goals require planning and programmatic responses that will permit educational success and university entrance in a tight time frame. Throughout this time these students will be in the process of developing their English language proficiency, and they will be particularly disadvantaged in academic content areas of study where the linguistic burden is significant, namely, the English literature courses.

The key to academic success for these students lies in making wise timetabling decisions while organizing for ESL support that will advance the students through an academic sequence of courses that have been identified as the gatekeepers to success. Many of the suggestions presented in this article for timetable reform are cost-neutral. Others require reallocation of resources to respond to the extended need for ESL instructional support and for professional development of mainstream teachers.

Respecting the notion of linguistic threshold levels (timing), sequencing, and distributing the workload are all aspects of the theme of time that administrators need to take into account when building the school timetable. When timetabling decisions reflect student learning needs and instructional goals, significant gains can be made by ESL learners.

As we move into the new millennium, we cannot avoid the needs of an ever-growing group of students who seek to make their future in Canada. 
Their future is our future. They have chosen Canada as their second home: will we respond by ensuring equitable opportunities for these students to realize their full potential?

\section{Acknowledgments}

The authors would like to thank Pat Mathews and Sandie Kouritzin, Editors of TESL Canada Journal, for their generous support in preparing the manuscript for publication. We are grateful to the three anonymous reviewers for their feedback in the revisions stage. Chuck Eastly, guidance counselor; Pat Kover, English Department Head; and Ben Bombier, Sheltered English 10 teacher all deserve special recognition for their work with the ESL students. Finally, we are grateful to the ESL students in the graduating classes of 1998, 1999, 2000 who gave us an unblemished record for English 30 success. You inspired us-congratulations!

\section{The Authors}

Hetty Roessingh is an assistant professor in the Faculty of Education, University of Calgary. She was an ESL teacher with the Calgary Board of Education. Interests include action research related to the academic success of ESL learners, curriculum, and tracking studies.

Diane Field is the principal of Queen Elizabeth Jr. and Sr. High School in Calgary. She is a strong advocate for ESL programming, and supports classroom based research that will account for academic success.

\section{References}

Alberta Education. (1992). Achieving the vision report. Edmonton, AB: Author.

Alberta Education. (1997). Examiner's report [On-line]. Available: www. ednet@edc.gov.ca.

Bogdan, R., \& Biklen, S. (1992). Qualitative education for education: An introduction to theory and methods. Toronto, ON: Allyn and Bacon.

Chiang, C., \& Dunkel, P. (1992). The effect of speech modification, prior knowledge, and listening proficiency of EFL lecture learning. TESOL Quarterly, 26, 345-374.

Citizenship and Immigration Canada. (1997). Staying the course: 1997 annual immigration plan. Ottawa: Author.

Collier, V. (1987). Age and rate of acquisition of second languages for academic purposes. TESOL Quarterly, 21, 617-641.

Collier, V. (1989). How long? A synthesis of research on academic achievement in a second language. TESOL Quarterly, 23, 509-531.

Cummins, J. (1982, February). Tests, achievement and bilingual students. Focus, 9. Wheaton, MD: National Clearinghouse for Bilingual Education.

Cummins, J. (1994). The acquisition of English as a second language. In K. SpangenbergUrbschat \& R. Pritchard (Eds.), Kids come in all languages (pp. 36-62). Newark, DE: International Reading Association.

Dawson, C. (1998, November 14). ESL students strain public board. Calgary Herald, B9.

Dempster, L., \& Alberts, S. (1998, February 18). Calgary a leader in ethnic minorities. Calgary Herald, A1-2.

Derwing, T., de Corby, E., Ichikawa, J., \& Jamieson, K. (1999). Some factors that affect the success of ESL high school students. Canadian Modern Language Review, 55, 532-547.

Duffy, A. (1999, November 2). 300,000 immigrants needed each year: Ottawa. Calgary Herald, A1-2.

Eddy, C. (1999, May). The forces who shape us. Paper presented to the TESL ' 99 Conference, Meeting the Millennium, Banff.

Employment and Immigration Canada. (1985). Annual report to parliament on future immigration levels. Ottawa: Author. 
Foscolos, D. (2000). ESL students' perceptions of their high school learning experiences. Unpublished master's thesis, University of Calgary.

Grabe, W. (1991). Current developments in second language reading research. TESOL Quarterly, 25, 375-406.

Jedwab, J. (2000). As the world turns: A profile of Canadian immigration at the century's end. Background paper 3, Association for Canadian Studies. Montreal, QC: McGill University.

Kanno, Y., \& Applebaum, S. (1995). ESL students speak up: Their stories of how we are doing. TESL Canada Journal, 12(2), 32-49.

Kentta, B. (1993). The challenge of an integrated curriculum. School Administrator, 3(50), 17-19.

Kessler, C. (1987). ESL and science learning. In JoAnn Crandall (Ed.), ESL through content-area instruction (pp. 55-87). Englewood Cliffs, NJ: Prentice-Hall.

McInnes, C. (1993, May 3). First you have to learn English. Globe and Mail, A1.

Miller,, G., \& Gildea, P. (1987). How children learn words. Scientific American, 257, pp. 86-91.

Radwanski, G. (1987). Ontario study of the relevance of education and the issue of dropouts. Toronto, ON: Ontario Ministry of Education.

Rinehart, D. (1996, November 21). The ESL quandary. Vancouver Sun, Saturday Revier,, D4-5.

Roessingh, H. (1996). ESL students and the inclusive high school science class: An investigation into the effects of curriculum restructuring. Unpublished doctoral dissertation, University of Calgary.

Roessingh, H. (1999). Adjunct support for high school ESL learners in mainstream English classes: Ensuring success. TESL Canada Journal, 17(1), 72-86.

Schroth, G. (1997). Fundamentals of school scheduling. Lancaster, PA: Technomic.

Strauss, A. (1987). Qualitative analysis for social scientists. Cambridge, MA: Cambridge University Press.

Watt, D., \& Roessingh, H. (1994). ESL dropout: The myth of educational equity. Alberta Journal of Educational Research, 40, 283-296.

Watt, D., \& Roessingh, H. (2000). The dynamics of ESL dropout: Plus ça change. Unpublished manuscript

Watt, D., Roessingh, H., \& Bosetti, L. (1996). Success and failure: Stories of ESL students' educational and cultural adjustment to high school. Urban Education, 31, 199-221.

\section{Appendix: Questionnaire for Grade 12 Students}

Congratulations! You are on the "home stretch"! Please reflect back on your years in high school, and answer these questions with regard to time, timing and timetabling. The idea behind this questionnaire is to understand what has contributed to your success in high school and most especially, the relationship between time, English language development and your success in content courses.

Think back to your starting point in Grade 10, the level of English you had, and your timetable. Make a timetable for a Grade 10 student like yourself that would permit success.

Grade 10

\begin{tabular}{|l|l|}
\hline Semester 1 & Semester 2 \\
\hline & \\
\hline & \\
\hline & \\
\hline
\end{tabular}

Explain the selection and sequencing of the courses you have put on the timetable below: 
Would you recommend summer school after Grade 10 ?

What courses(s) are suitable for summer school?

\section{Explain:}

Now create timetables for the Grade 11 and 12 year that you think make sense for a student who wants to go to university.

Grade 11

\begin{tabular}{|l|l|}
\hline Semester 1 & Semester 2 \\
\hline & \\
\hline & \\
\hline & \\
\hline & \\
\hline
\end{tabular}

Summer school? Courses:

Explain the course sequencing and selection that you have put on the timetable above:

Grade 12

\begin{tabular}{|l|l|}
\hline Semester 1 & Semester 2 \\
\hline & \\
\hline & \\
\hline & \\
\hline
\end{tabular}

Explain the course selection and sequencing you have put on the timetable above:

When you look at the timetables you have created, what do you notice most?

Do you have any regrets about your high school program? (not enough fun or time to do option courses, too intense to go through high school like this-should simply have planned for a fourth year, etc.)

Probably the single most critical step is into English 10. How do you know when you are ready to take this course?

What helped you get through high school?

What help would have liked that you didn't get?

What words of advice do you have for younger students coming through high school behind you? 